Ariyanti, M. - S. Yahya - K. Murtilaksono - Suwarto - H.H. Siregar

\title{
Pengaruh tanaman penutup tanah Nephrolepis biserrata dan teras gulud terhadap aliran permukaan dan pertumbuhan kelapa sawit (Elaeis guineensis Jacq.)
}

\section{The influence of cover crop Nephrolepis biserrata and ridge terrace against run off and the growth of oil palm (Elaeis guineensis Jacq.).}

Diterima : 15 Juli 2016/Disetujui : 10 Agustus 2016 / Dipublikasikan : 30 Agustus 2016

CDepartment of Crop Science, Padjadjaran University

\begin{abstract}
Planting cover crop (CC) is considered as an activity that supports ISPO (Indonesian Sustainable Palm Oil System), which is plant maintenance in order to support its productivity. Nephrolepis biserrata is one of weed which grows in the oil palm plantation, tolerant shade, so that it can be grown as cover crop on oil palm plantation. Mechanically ridge terraces applied as conservation technique which is a join match of planting CC in reducing run off, increasing infiltration so that support the growth and the production of oil palm. This study aims to know how much $N$. biserrata and ridge terrace able to reduce run off and its effect on the growth of oil palm .The research was done on August 2014 until April 2015 at oil palm plantation PTPN VII, Rejosari, South Lampung, used split block design. The result showed plots which ridge terraces and N. biserrata planted, plots without ridge terraces and $N$. biserrata planted, plots with ridge terraces without $N$. biserrata planted effectively reduced the flow of the surface respectively $95.7 \%, 80.0 \%$ and $63.4 \%$. A ridge terrace and planting of $N$. biserrata as cover crop influenced the growth of oil palm especially on the amount of leaves and the amount of the fall leaves.
\end{abstract}

Keywords : Nephrolepis biserrata . Cover crop . Ridge terrace $\cdot$ Oil palm

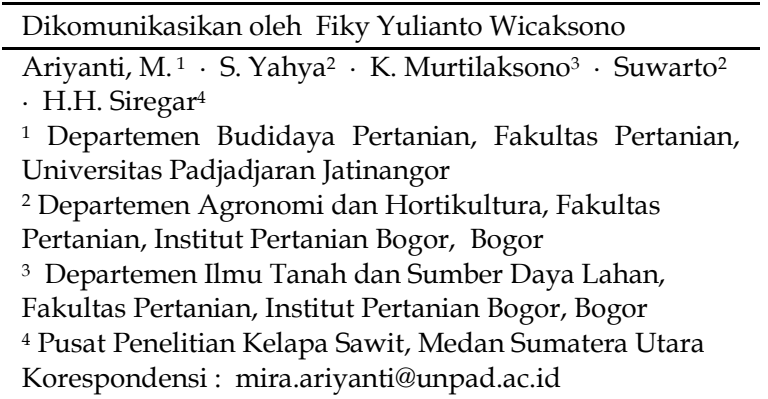

Sari Penanaman tanaman penutup tanah (TPT) dikategorikan sebagai kegiatan yang mendukung ISPO (Indonesian Sustainable Palm Oil System) yaitu pemeliharaan tanaman dalam mendukung produktivitas tanaman. Nephrolepis biserrata merupakan salah satu gulma yang banyak tumbuh di kebun kelapa sawit, toleran naungan sehingga dapat ditanam sebagai TPT di areal kebun kelapa sawit menghasilkan. Secara mekanik, diaplikasikan teras gulud sebagai bangunan konservasi yang merupakan paduan penanaman TPT dalam mengurangi aliran permukaan, meningkatkan resapan air ke dalam tanah sehingga mendukung pertumbuhan dan produksi kelapa sawit. Penelitian ini bertujuan mengetahui berapa besar $N$. biserrata dan teras gulud mengurangi aliran permukaan dan pengaruhnya terhadap pertumbuhan kelapa sawit. Penelitian dilakukan bulan Agustus 2014-April 2015 di unit usaha Rejosari PTPN VII, Lampung Selatan, menggunakan rancangan blok terpisah. Hasil penelitian menunjukkan lahan yang diberi teras gulud dan ditanami $N$. biserrata, tanpa teras gulud dan ditanami $N$. biserrata, teras gulud tanpa ditanami $N$. biserrata efektif mengurangi aliran permukaan berturut-turut sebesar $95.7 \%, 80.0 \%$ dan $63.4 \%$. Teras gulud dan tanaman penutup tanah $N$. biserrata mempengaruhi pertumbuhan kelapa sawit terutama pada peubah pertumbuhan jumlah pelepah dan jumlah pelepah patah.

Kata kunci : Nephrolepis biserrata Tanaman penutup tanah - Teras gulud · Aliran permukaan - Kelapa sawit

\section{Pendahuluan}

Areal kebun kelapa sawit yang memiliki topografi lahan dengan keadaan lereng yang cenderung beragam akan rentan untuk 
terjadinya erosi dan aliran permukaan. Hal ini merupakan salah satu faktor yang dapat menyebabkan berkurangnya cadangan air tanah. Kandungan air tanah merupakan peubah ketersediaan air tanah yang dapat dimanfaatkan oleh tanaman untuk mendukung pertumbuhan dan perkembangannya. Pada keadaan terkurasnya cadangan air tanah maka suplai air bagi tanaman akan sangat terbatas bahkan cenderung terjadinya kekeringan pada tanaman. Ketersediaan air sepanjang waktu dalam jumlah yang cukup merupakan syarat penting di samping pemenuhan unsur-unsur hara agar tanaman kelapa sawit dapat tumbuh dan berproduksi optimal. Tanaman kelapa sawit berkembang baik pada daerah dengan curah hujan lebih dari $2000 \mathrm{~mm} /$ tahun, tanpa periode kering yang nyata atau bulan kering kurang dari satu bulan per tahun (Adiwiganda et al. 1999).

Saat ini telah diterapkan pembuatan teras gulud pada lahan kebun bertujuan menghambat aliran permukaan dan mengurangi erosi yang terjadi. Penelitian mengenai teras gulud menunjukkan hasil bahwa perlakuan guludan dan perlakuan rorak mampu menyimpan cadangan air tanah tahunan lebih besar daripada kontrol, yaitu $4235.3 \mathrm{~mm}$ untuk perlakuan guludan $3834.2 \mathrm{~mm}$ untuk kontrol, dan $4877 \mathrm{~mm}$ untuk perlakuan rorak (Pratiwi 2008). Selain itu perlakuan guludan dan perlakuan rorak mempunyai nilai produksi tandan kelapa sawit (TBS) yang lebih besar dibandingkan dengan kontrol, dimana nilai TBS pada perlakuan guludan, kontrol, dan perlakuan rorak masing-masing sebesar $25 \mathrm{ribu} ; 21$ ribu dan $24 \mathrm{ribu} \mathrm{kg} / \mathrm{ha} / \mathrm{th}$. Hal ini menunjukkan bahwa terdapat korelasi positif antara cadangan air tanah dengan produksi tandan kelapa sawit (Pratiwi 2008).

Penelitian Brata et al. (1992) menunjukkan bahwa teknik konservasi tanah dan air berupa pembuatan guludan yang dilengkapi dengan saluran berserasah (mulsa vertikal) sangat nyata menurunkan aliran permukaan dan erosi. Penerapan guludan bersaluran yang diberi serasah tersebut dengan jarak antar guludan 5.5 $\mathrm{m}$ dapat menurunkan aliran permukaan $73.6 \%$ pada penanaman jagung (Suryana 1993), dan sebesar $89 \%$ pada pertanaman kacang tanah (Tobing 1994). Efektivitas guludan dalam menurunkan erosi dapat mencapai 5\% pada lereng yang sedang tetapi akan menurun pada lereng yang lebih curam (Sinukaban 1985). Guludan bersaluran dapat dibuat pada tanah dengan lereng sampai 12\% (Arsyad 2010).
Tanaman penutup tanah ternyata sangat bermanfaat dalam memperbaiki sifat fisik tanah terutama struktur. Chan et al. (1973) melaporkan bahwa tanaman penutup tanah secara efektif dapat memperbaiki struktur tanah liat sehingga berpengaruh positif terhadap pertumbuhan tanaman utama. Hasil penelitian Nasution (1984) menunjukkan bahwa konsistensi tanah pada tanaman penutup tanah serelium adalah gembur, agak gembur pada tanaman penutup tanah kacangan campuran dan teguh-sangat teguh pada tanah tanpa tanaman penutup tanah. Pengaruh tanaman penutup terhadap erosi dan aliran permukaan dapat dibagi ke dalam empat bagian yaitu : (1) intersepsi curah hujan oleh tajuk tanaman, (2) mengurangi kecepatan aliran permukaan dan kekuatan perusak dari air, (3) pengaruh akar dan kegiatan biologi yang berhubungan dengan pertumbuhan vegetatif dan pengaruhnya terhadap porositas tanah, dan (4) transpirasi yang menyebabkan keringnya tanah (Arsyad 2010).

Menurut Kartasapoetra (1989), terdapat beberapa syarat penggunaan tumbuhan sebagai tanaman penutup tanah, yaitu: tidak menjadi kompetitor bagi tanaman utama dalam pemanfaatan sumberdaya alam, pertumbuhan cepat, rapat dan rimbun, mampu bersaing dengan gulma, tidak menjadi inang bagi hama dan penyakit yang dapat menyerang tanaman utama. Penelitian ini bertujuan untuk mengetahui berapa besar $N$. biserrata dan teras gulud dapat mengurangi aliran permukaan dan pengaruhnya terhadap pertumbuhan dan produksi kelapa sawit.

\section{Bahan dan Metode}

Penelitian dilaksanakan di Afdeling I (tanpa teras gulud) dan afdeling III (dengan teras gulud) Unit Usaha (UU) Rejosari PT Kebun Nusantara (PTPN) VII, Kecamatan Natar, Kabupaten Lampung Selatan. Afdeling I meliputi blok 296 (tahun tanam 2005), blok 415 (tahun tanam 1996), blok 457 (tahun tanam 2001). Afdeling III meliputi blok 295 (tahun tanam 2005), blok 375 (tahun tanam 1996), blok 377 (tahun tanam 2001). Waktu penelitian bulan Agustus 2014-April 2015.

Metode penelitian menggunakan rancangan blok terpisah (split block design) dalam rancangan acak kelompok. Rancangan ini terdiri dari 2 faktor yaitu teras gulud $(G)$ sebagai petak utama, tanaman penutup tanah $(\mathrm{T})$ sebagai anak petak. Faktor perlakuannya adalah : 
Petak utama : teras gulud terdiri dari 2 taraf yaitu,

$\mathrm{G}_{0}=$ tanpa teras gulud

$\mathrm{G}_{1}=$ dengan teras gulud

Anak petak : Tanaman penutup tanah (T) terdiri dari 2 taraf yaitu,

$\mathrm{T}_{0}=$ tanpa tanaman penutup tanah

$\mathrm{T}_{1}=$ ditanami tanaman penutup tanah $N$. biserrata

Data hasil pengamatan dianalisis dengan uji $\mathrm{F}$ pada taraf $5 \%$ (analisis ragam), apabila berpengaruh nyata dilanjutkan dengan uji Beda Nyata Terkecil (BNT) pada taraf 5\%.

\section{Hasil dan Pembahasan}

Hujan yang jatuh ke permukaan tanah cenderung akan hilang sebagai aliran permukaan yang dapat menyebabkan erosi. Hal tersebut dapat dihindari dengan adanya tanaman penutup tanah yang berfungsi sebagai penahan aliran hujan melalui sistem tajuk dan perakarannya sehingga aliran permukan yang terjadi dapat ditekan. Tajuk dapat mengurangi besarnya air hujan yang jatuh langsung ke permukaan tanah dan sistem perakaran tanaman dapat mengurangi aliran permukaan yang terjadi, membantu air lebih lama tertahan akar yang melekat pada tanah sebagai media tanamnya sehingga dapat lebih meresap ke dalam tanah yang pada akhirnya akan mempengaruhi kadar air tanah.

Pengaruh teras gulud dan tanaman penutup tanah $N$. biserrata terhadap aliran permukaan pada petak erosi di kebun kelapa sawit PTPN VII Rejosari, Lampung Selatan ditunjukkan pada Tabel 1. Seluruh perlakuan baik teras gulud maupun tanaman penutup tanah memberikan pengaruh nyata terhadap aliran permukaan yang terjadi. Aliran permukaan terendah terjadi bulan Maret 2014 pada petak perlakuan dengan teras gulud dan ditanami $N$. biserrata $\left(\mathrm{G}_{1} \mathrm{~T}_{1}\right)$ dengan curah hujan sebesar $116 \mathrm{~mm}$ dan yang tertinggi terjadi bulan April 2015 pada petak perlakuan tanpa teras gulud dan tanpa ditanami $N$. biserrata $\left(\mathrm{G}_{0} \mathrm{~T}_{0}\right)$ dengan curah hujan sebesar $175 \mathrm{~mm}$. Bulan Oktober 2014 dengan curah hujan kurang dari $60 \mathrm{~mm} /$ bulan, aliran permukaan terjadi pada perlakuan tanpa teras gulud tanpa ditanami $N$. biserrata $\left(\mathrm{G}_{0} \mathrm{~T}_{0}\right)$ dan perlakuan dengan teras gulud tanpa ditanami $N$. biserrata $\left(\mathrm{G}_{1} \mathrm{~T}_{0}\right)$. Hal ini menunjukkan bahwa $N$. biserrata sebagai tanaman penutup tanah berperan penting dalam mengurangi terjadinya aliran permukaan.

Aliran permukaan tertinggi cenderung terjadi pada saat terjadinya curah hujan tertinggi yaitu bulan Februari 2015, tetapi dengan adanya teras gulud dan tanaman penutup tanah $N$. biserrata hal tersebut dapat dihindari dan mengusahakan air hujan yang jatuh dapat lebih banyak meresap ke dalam tanah sehingga kadar air tanah dapat terjaga terutama pada musim kemarau. Terdapat kaitan erat dalam pengaruh $N$. biserrata terhadap neraca air di perkebunan kelapa sawit menghasillkan yaitu mengurangi terjadinya defisit air tanah pada musim kemarau atau bulan kering sebesar 36,71\% (Ariyanti et al. 2015).

Tabel 1. Pengaruh Teras Gulud dan Tanaman Penutup Tanah N. biserrata terhadap Aliran Permukaan pada Petak Erosi di Kebun Kelapa Sawit Tahun Tanam 1996, 2001, 2005 PTPN VII Rejosari, Lampung Selatan Bulan Oktober 2014 - April 2015.

\begin{tabular}{|c|c|c|c|c|c|c|c|c|c|}
\hline \multirow{3}{*}{ Bulan } & \multicolumn{8}{|c|}{ Perlakuan } & \multirow{3}{*}{$\begin{array}{l}\text { Jumlah } \\
\text { hari hujan }\end{array}$} \\
\hline & \multicolumn{2}{|c|}{$\mathrm{G}_{0} \mathrm{~T}_{0}$} & \multicolumn{2}{|c|}{$\mathrm{G}_{0} \mathrm{~T}_{1}$} & \multicolumn{2}{|c|}{$\mathrm{G}_{1} \mathrm{~T}_{0}$} & \multicolumn{2}{|c|}{$\mathrm{G}_{1} \mathrm{~T}_{1}$} & \\
\hline & $\begin{array}{c}\mathrm{AP} \\
(\mathrm{mm})\end{array}$ & $\begin{array}{c}\mathrm{CH} \\
(\mathrm{mm})\end{array}$ & $\begin{array}{c}\mathrm{AP} \\
(\mathrm{mm})\end{array}$ & $\begin{array}{c}\mathrm{CH} \\
(\mathrm{mm})\end{array}$ & $\mathrm{AP}(\mathrm{mm})$ & $\begin{array}{c}\mathrm{CH} \\
(\mathrm{mm})\end{array}$ & $\begin{array}{c}\mathrm{AP} \\
(\mathrm{mm})\end{array}$ & $\begin{array}{c}\mathrm{CH} \\
(\mathrm{mm})\end{array}$ & \\
\hline Okt 14 & $10.8 \mathrm{a}$ & 44.0 & $0.0 \mathrm{c}$ & 35.0 & $1.3 b$ & 24.0 & $0.0 \mathrm{c}$ & 34.0 & 1 \\
\hline Nov 14 & $135.7 \mathrm{a}$ & 194.0 & $68.6 b$ & 168.0 & $15.1 \mathrm{c}$ & 151.0 & $4.2 \mathrm{~d}$ & 147.0 & 5 \\
\hline Des 14 & $130.5 a$ & 221.0 & $11.3 c$ & 203.0 & $57.5 b$ & 219.0 & $3.3 \mathrm{~d}$ & 202.0 & 7 \\
\hline Jan 15 & $106.2 \mathrm{a}$ & 199.0 & $6.7 c$ & 176.0 & $20.8 b$ & 162.0 & $2.9 \mathrm{~d}$ & 180.0 & 9 \\
\hline Feb15 & $120.6 a$ & 231.0 & $38.3 c$ & 191.0 & $75.0 \mathrm{~b}$ & 251.0 & $12.5 \mathrm{~d}$ & 228.0 & 9 \\
\hline Mar 15 & $99.5 a$ & 144.0 & $5.8 \mathrm{c}$ & 120.0 & $32.1 b$ & 127.0 & $1.7 \mathrm{~d}$ & 116.0 & 7 \\
\hline Apr 15 & $113.7 \mathrm{a}$ & 175.0 & $12.5 \mathrm{c}$ & 183.0 & $60.8 b$ & 186.0 & $6.3 c$ & 190.0 & 7 \\
\hline Total & $717.0 \mathrm{a}$ & 1207.0 & $143.2 \mathrm{c}$ & 1077.0 & $262.6 \mathrm{~b}$ & 923.0 & $30.9 \mathrm{~d}$ & 1096.0 & 45 \\
\hline
\end{tabular}

Keterangan : $\mathrm{G}_{0}=$ tanpa teras gulud; $\mathrm{G}_{1}=$ dengan teras gulud; $\mathrm{T}_{0}=$ tanpa tanaman penutup tanah; $\mathrm{T}_{1}=$ dengan tanaman penutup tanah ( $N$. biserrata); $\mathrm{AP}=$ volume aliran permukaan; $\mathrm{CH}=$ curah hujan. Angka-angka pada baris yang sama yang diikuti oleh huruf yang sama tidak berbeda nyata berdasarkan uji BNT a 0.05. 
Aliran permukaan pada blok perlakuan dengan teras gulud tanpa ditanami $N$. biserrata $\left(\mathrm{G}_{1} \mathrm{~T}_{0}\right)$ dengan curah hujan sebesar $251 \mathrm{~mm}$ dan perlakuan dengan teras gulud ditanami $N$. biserrata $\left(\mathrm{G}_{1} \mathrm{~T}_{1}\right)$ dengan curah hujan sebesar 228 $\mathrm{mm}$ berbeda nyata dengan blok perlakuan tanpa teras gulud tidak ditanami $N$. biserrata $\left(\mathrm{G}_{0} \mathrm{~T}_{0}\right)$ dengan curah hujan sebesar $231 \mathrm{~mm}$. Hal ini menunjukkan bahwa dalam keadaan curah hujan yang relatif sama, teras gulud dan tanaman penutup tanah dapat menekan terjadinya aliran permukaan yang terjadi.

Teras gulud dan tanaman penutup tanah $N$. biserrata efektif dalam mengurangi terjadinya aliran permukaan terutama pada bulan dengan curah hujan yang tinggi. Kemampuan tanah dalam menyerapkan air ke dalamnya dapat lebih ditingkatkan dengan adanya teras gulud dan tanaman penutup tanah. Akar tanaman yang terikat kuat pada partikel tanah dapat menahan aliran air agar tidak terlalu deras pada saat terjadi hujan lebat. Tajuk tanaman berperan dalam mengurangi banyaknya air hujan yang jatuh ke tanah karena ada sebagian air yang diintersepsikan oleh tanaman, selain itu bagian tanaman yang gugur dan jatuh ke permukaan tanah dapat membantu memperbaiki sifat fisik, kimia dan biologi tanah yang pada akhirnya akan berperan kemampuan tanah dalam memegang air.

Persentase air hujan yang menjadi aliran permukaan tertinggi ditunjukkan oleh perlakuan tanpa teras gulud dan tanpa tanaman penutup tanah $\left(\mathrm{G}_{0} \mathrm{~T}_{0}\right)$ sebesar $59.4 \%$. Perlakuan teras gulud, ditanami $N$. biserrata $\left(\mathrm{G}_{1} \mathrm{~T}_{1}\right)$ efektif mengurangi aliran permukaan sebesar $95.7 \%$ dengan persentase aliran permukaan $2.8 \%$ dari air hujan yang terjadi, sedangkan perlakuan tanpa teras gulud, ditanami $N$. biserrata $\left(\mathrm{G}_{0} \mathrm{~T}_{1}\right)$ dan perlakuan teras gulud tanpa ditanami $N$. biserrata $\left(\mathrm{G}_{1} \mathrm{~T}_{0}\right)$ efektif mengurangi aliran permukaan berturut-turut sebesar $80.0 \%$ dan $63.4 \%$ dengan persentase aliran permukaan $13.3 \%, 28.5 \%$ dari air hujan (Tabel 2). Hal ini sejalan dengan penelitian lain yaitu penerapan guludan bersaluran yang diberi serasah dengan jarak antar guludan $5.5 \mathrm{~m}$ dapat menurunkan aliran permukaan $73.6 \%$ pada penanaman jagung (Suryana 1993), dan sebesar 89\% pada pertanaman kacang tanah (Tobing 1994). Penelitian Brata et al. (1992) menunjukkan bahwa teknik konservasi tanah dan air berupa pembuatan guludan yang dilengkapi dengan saluran berserasah (mulsa vertikal) sangat nyata menurunkan aliran permukaan dan erosi.
Pengaruh tanaman penutup terhadap erosi dan aliran permukaan dapat dibagi ke dalam empat bagian yaitu : (1) intersepsi curah hujan oleh tajuk tanaman, (2) mengurangi kecepatan aliran permukaan dan kekuatan perusak dari air, (3) pengaruh akar dan kegiatan biologi yang berhubungan dengan pertumbuhan vegetatif dan pengaruhnya terhadap porositas tanah, dan (4) transpirasi yang menyebabkan keringnya tanah (Arsyad 2010).

Kemampuan tanah dalam menyimpan air akan berpengaruh terhadap pertumbuhan tanaman yang hidup di atasnya. Tanaman kelapa sawit berkembang baik pada daerah dengan curah hujan lebih dari $2000 \mathrm{~mm} /$ tahun, tanpa periode kering yang nyata atau bulan kering kurang dari satu bulan per tahun (Adiwiganda et al. 1999). Lingkungan dengan curah hujan rendah dapat menyebabkan kadar air tanah rendah sehingga berdampak berkurangnya suplai air bagi kelapa sawit. Tabel 3 dan Tabel 4 memperlihatkan peubah pertumbuhan kelapa sawit tahun tanam 1996 di petak erosi yang diberi perlakuan. Rata-rata jumlah pelepah, rata-rata jumlah anak daun, rata-rata panjang anak daun, rata-rata lebar anak daun dan panjang rachis yang merupakan peubah pertumbuhan ditunjukkan pada Tabel 3. Tabel 4 menunjukkan peubah pertumbuhan lainnya yaitu jumlah pelepah sengkleh, luas daun, ILD.

Rata-rata panjang rachis, jumlah anak daun, rata-rata panjang anak daun, rata-rata lebar anak daun, panjang rachis, luas daun dan ILD kelapa sawit pada setiap perlakuan teras gulud dan penanaman $N$. biserrata menunjukkan adanya peningkatan dari bulan Agustus 2014 sampai dengan April 2015. Peubah pertumbuhan tersebut lebih dipengaruhi oleh genetik tanaman dibandingkan dengan pengaruh lingkungan. Pengaruh tanaman penutup tanah dan teras gulud tampaknya terlihat pada bulan Desember 2014 dan April 2015. Bulan Desember dengan curah hujan di atas $200 \mathrm{~mm}$, perlakuan $\mathrm{G}_{1} \mathrm{~T}_{1}$ menghasilkan pelepah 21.3\% lebih banyak dibandingkan perlakuan $\mathrm{G}_{0} \mathrm{~T}_{0}$ dan perlakuan $\mathrm{G}_{1} \mathrm{~T}_{0}$ menghasilkan $13.8 \%$ lebih banyak dibandingkan $\mathrm{G}_{0} \mathrm{~T}_{0}$. Hal ini disebabkan oleh jumlah curah hujan yang dapat terinfiltrasi ke dalam tanah lebih banyak dengan adanya teras gulud dan tanaman penutup tanah N. biserrata. Pada bulan April 2015 kelapa sawit dengan perlakuan $\mathrm{G}_{0} \mathrm{~T}_{1}$ menghasilkan jumlah pelepah yang sama dengan perlakuan $\mathrm{G}_{1} \mathrm{~T}_{1}$. Hal ini menunjukkan bahwa $N$. biserrata sangat baik ditanam sebagai tanaman penutup tanah karena 
keberadaannya baik melalui sistem perakarannya dapat meningkatkan kadar air tanah dalam menyimpan air sehingga berpengaruh baik terhadap pertumbuhan pelepah kelapa sawit.

Penurunan jumlah pelepah yang terjadi disebabkan adanya kegiatan penunasan yang rutin dilakukan pada kebun kelapa sawit yang bertujuan untuk meningkatkan pertumbuhan pelepah baru. Pemangkasan atau penunasan pada tanaman kelapa sawit adalah pembuangan pelepah daun (frond). Pelepah yang dipotong adalah pelepah yang sudah tua dan tidak berfungsi lagi dalam proses asimilasi. Pelepah yang masih muda tidak boleh dipotong karena daya asimilasinya masih tinggi dan mengan- dung zat makanan, karena menjelang kering zat makanan dari pelepah tua ditransfer ke pelepah yang lebih muda untuk memacu pertumbuhan tanaman terutama unsur yang sangat mobil seperti K dan Mg. Tanaman kelapa sawit memproduksi pelepah terus-menerus sepanjang tahun dengan rata-rata $2-3$ pelepah sebulan.

Jumlah pelepah yang ada dipengaruhi pula oleh pelepah yang mengalami sengkleh karena kurangnya suplai air yang dibutuhkan oleh tanaman kelapa sawit. Hal ini terutama terjadi pada perlakuan $\mathrm{G}_{0} \mathrm{~T}_{0}, \mathrm{G}_{1} \mathrm{~T}_{0}$ yang cenderung mengalami penurunan jumlah pelepah pada setiap periode pengamatan peubah produksi yang dilakukan. Pada periode Agustus 2014 -

Tabel 2. Pengaruh Teras Gulud dan Tanaman Penutup Tanah N. biserrata terhadap Aliran Permukaan Total di Kebun Kelapa Sawit Tahun Tanam 1996, 2001, 2005 PTPN VII Rejosari, Lampung Selatan.

\begin{tabular}{ccccc}
\hline \hline Perlakuan & $\begin{array}{c}\text { Aliran permukaan } \\
\text { (mm/tahun) }\end{array}$ & $\begin{array}{c}\text { Jumlah curah } \\
\text { hujan } \\
(\mathrm{mm} / \text { tahun })\end{array}$ & $\begin{array}{c}\text { Persentase aliran } \\
\text { permukaan }(\%)\end{array}$ & $\begin{array}{c}\text { Efektivitas } \\
\text { perlakuan } \\
(\%)\end{array}$ \\
\hline $\mathrm{G}_{0} \mathrm{~T}_{0}$ & $717.0 \mathrm{a}$ & 1207.0 & 59.4 & - \\
$\mathrm{G}_{0} \mathrm{~T}_{1}$ & $143.2 \mathrm{c}$ & 1077.0 & 13.3 & 80.0 \\
$\mathrm{G}_{1} \mathrm{~T}_{0}$ & $262.6 \mathrm{~b}$ & 923.0 & 28.5 & 63.4 \\
$\mathrm{G}_{1} \mathrm{~T}_{1}$ & $30.9 \mathrm{~d}$ & 1096.0 & 2.8 & 95.7 \\
\hline \hline
\end{tabular}

Keterangan : $\mathrm{G}_{0}=$ tanpa teras gulud; $\mathrm{G}_{1}=$ dengan teras gulud; $\mathrm{T}_{0}=$ tanpa tanaman penutup tanah; $\mathrm{T}_{1}=$ dengan tanaman penutup tanah $(N$. biserrata)

Angka-angka pada kolom yang sama yang diikuti oleh huruf yang sama tidak berbeda nyata berdasarkan uji BNT a 0.05 .

Tabel 3. Rata-rata Jumlah Pelepah, Rata-rata Panjang Rachis, Rata-rata Jumlah Anak Daun, Rata-rata Panjang Anak Daun, Rata-rata Lebar Anak Daun pada Petak Erosi di Kebun Kelapa Sawit Tahun Tanam 1996 PTPN VII Rejosari, Lampung Selatan Bulan Agustus 2014, Desember 2014, April 2015 *).

\begin{tabular}{|c|c|c|c|c|c|c|}
\hline \multirow[b]{2}{*}{ Bulan } & \multirow[b]{2}{*}{ Perlakuan } & \multicolumn{5}{|c|}{ Peubah pertumbuhan } \\
\hline & & $\begin{array}{c}\text { Rata-rata } \\
\text { jumlah } \\
\text { pelepah }\end{array}$ & $\begin{array}{l}\text { Rata-rata } \\
\text { panjang } \\
\text { rachis }(\mathrm{m})\end{array}$ & $\begin{array}{c}\text { Rata-rata } \\
\text { jumlah anak } \\
\text { daun }\end{array}$ & $\begin{array}{c}\text { Rata-rata } \\
\text { panjang anak } \\
\text { daun }(\mathrm{cm})\end{array}$ & $\begin{array}{c}\text { Rata-rata lebar } \\
\text { anak daun } \\
(\mathrm{cm})\end{array}$ \\
\hline \multirow{4}{*}{ Agustus 2014} & $\mathrm{G}_{0} \mathrm{~T}_{0}$ & 41.0 & 7.3 & 372.1 & 96.5 & 5.0 \\
\hline & $\mathrm{G}_{0} \mathrm{~T}_{1}$ & 41.3 & 7.3 & 372.1 & 96.7 & 5.0 \\
\hline & $\mathrm{G}_{1} \mathrm{~T}_{0}$ & 41.3 & 7.3 & 372.0 & 96.1 & 5.0 \\
\hline & $\mathrm{G}_{1} \mathrm{~T}_{1}$ & 41.5 & 7.3 & 372.1 & 96.1 & 5.0 \\
\hline \multirow{4}{*}{ Desember 2014} & $\mathrm{G}_{0} \mathrm{~T}_{0}$ & 40.0 & 7.3 & 373.6 & 98.0 & 5.1 \\
\hline & $\mathrm{G}_{0} \mathrm{~T}_{1}$ & 40.3 & 7.4 & 373.7 & 97.8 & 5.1 \\
\hline & $\mathrm{G}_{1} \mathrm{~T}_{0}$ & 45.5 & 7.4 & 373.4 & 97.0 & 5.0 \\
\hline & $\mathrm{G}_{1} \mathrm{~T}_{1}$ & 48.5 & 7.4 & 373.3 & 97.2 & 5.0 \\
\hline \multirow{4}{*}{ April 2015} & $\mathrm{G}_{0} \mathrm{~T}_{0}$ & 40.5 & 7.4 & 375.8 & 98.6 & 5.1 \\
\hline & $\mathrm{G}_{0} \mathrm{~T}_{1}$ & 45.0 & 7.4 & 374.4 & 98.0 & 5.1 \\
\hline & $\mathrm{G}_{1} \mathrm{~T}_{0}$ & 41.0 & 7.4 & 374.8 & 98.4 & 5.0 \\
\hline & $\mathrm{G}_{1} \mathrm{~T}_{1}$ & 45.0 & 7.4 & 374.8 & 98.3 & 5.0 \\
\hline
\end{tabular}

Keterangan : $\mathrm{G}_{0}=$ tanpa teras gulud; $\mathrm{G}_{1}=$ dengan teras gulud; $\mathrm{T}_{0}=$ tanpa tanaman penutup tanah; $\mathrm{T}_{1}=$ dengan tanaman penutup tanah ( $N$. biserrata).

*) Hasil pengamatan di lapangan bersama Yenni Asbur dengan kajian yang berbeda. 
Desember 2014, terjadi peningkatan jumlah pelepah sebesar $16 \%$ dengan adanya perlakuan $\mathrm{G}_{1} \mathrm{~T}_{1}$ dan peningkatan ini lebih tinggi dibandingkan dengan perlakuan $\mathrm{G}_{1} \mathrm{~T}_{0}$ sebesar $7.5 \%$.

Pada periode Agustus - Desember 2014 terjadi hujan pada bulan Oktober dan November yang menyebabkan kadar air tanah meningkat dan hal ini didorong dengan adanya tanaman penutup tanah sehingga suplai air bagi tanaman kelapa sawit dapat terpenuhi. Pada periode Desember 2014 - April 2015, peningkatan jumlah pelepah terjadi di petakan dengan perlakuan $\mathrm{G}_{0} \mathrm{~T}_{1}$ sebesar $12.5 \%$, sedangkan untuk perlakuan lainnya jumlah pelepah cenderung menurun. Hal ini disebabkan adanya hujan yang cukup tinggi di petak $\mathrm{G}_{0} \mathrm{~T}_{1}$ berkisar $120-203 \mathrm{~mm}$ dan dengan adanya tanaman penutup tanah efektif dapat meningkatkan kadar air tanah sehingga mempengaruhi jumlah pelepah yang dihasilkan.

Patah pangkal pelepah pada tanaman kelapa sawit dikenal istilah sengkleh, sering juga disebut daun terkulai. Kurangnya air pada saat musim kemarau dapat menjadi pemicu munculnya gejala sengkleh (Purba 2009). Jumlah pelepah sengkleh merupakan indikator respon tanaman kelapa sawit terhadap kekeringan dimana semakin banyak jumlah pelepah sengkleh maka tanaman tersebut cenderung mengalami kekeringan. Banyaknya jumlah pelepah sengkleh pada bulan
Agustus 2014 mengindikasikan bahwa pada bulan tersebut terjadi kondisi kekeringan. Agustus 2014 merupakan bulan tidak ada hujan sama sekali. Pada tanaman kelapa sawit, kekeringan menyebabkan adanya pelepah sengkleh karena terjadi perubahan potensial air, potensial osmotik dan potensial turgor sel yang pada akhirnya mempengaruhi penutupan stomata. Perubahan ini mempengaruhi absorbsi dan translokasi hara mineral, transpirasi, fotosintesis dan translokasi fotosintesis (Kirkham 1990). Hal ini mengakibatkan menurunnya laju fotosintesis dan organ fotosintesis daun) mengalami penua-an dini, mengering dan patah untuk mengu-rangi evapotranspirasi (Mahamooth et al. 2008).

Penurunan jumlah pelepah sengkleh terjadi seiring dengan meningkatnya jumlah hujan pada bulan Desember 2014 dan April 2015 terutama pada perlakuan dengan teras gulud dan ditanami $N$. biserrata yang dapat menghilangkan jumlah pelepah sengkleh yang merupakan indikator semakin terpenuhinya suplai air bagi tanaman kelapa sawit tersebut. Keadaan curah hujan yang terjadi pada bulan Desember 2014 untuk petak $\mathrm{G}_{0} \mathrm{~T}_{0}, \mathrm{G}_{0} \mathrm{~T}_{1}, \mathrm{G}_{1} \mathrm{~T}_{0}$, $\mathrm{G}_{1} \mathrm{~T}_{1}$ berturut-turut sebesar $221 \mathrm{~mm}, 203 \mathrm{~mm}$, $219 \mathrm{~mm}, 202 \mathrm{~mm}$ sedangkan pada bulan April 2015 keadaan curah hujan untuk petak $\mathrm{G}_{0} \mathrm{~T}_{0}$, $\mathrm{G}_{0} \mathrm{~T}_{1}, \mathrm{G}_{1} \mathrm{~T}_{0}, \mathrm{G}_{1} \mathrm{~T}_{1}$ berturut-turut sebesar $175 \mathrm{~mm}$, $183 \mathrm{~mm}, 186 \mathrm{~mm}, 190 \mathrm{~mm}$.

Tabel 4. Jumlah Pelepah Sengkleh, Rata-rata Luas Daun, Indeks Luas Daun (ILD) pada Petak Erosi di Kebun Kelapa Sawit Tahun Tanam 1996 PTPN VII Rejosari, Lampung Selatan Bulan Agustus 2014, Desember 2014, April 2015*).

\begin{tabular}{|c|c|c|c|c|}
\hline \multirow[b]{2}{*}{ Bulan } & \multirow[b]{2}{*}{ Perlakuan } & \multicolumn{3}{|c|}{ Peubah pertumbuhan } \\
\hline & & $\begin{array}{l}\text { Jumlah pelepah } \\
\text { sengkleh/pohon }\end{array}$ & $\begin{array}{c}\text { Rata-rata luas } \\
\text { daun/pohon }\left(\mathrm{m}^{2}\right)\end{array}$ & ILD \\
\hline \multirow{4}{*}{ Agustus 2014} & $\mathrm{G}_{0} \mathrm{~T}_{0}$ & 16.3 & 9.90 & 5.80 \\
\hline & $\mathrm{G}_{0} \mathrm{~T}_{1}$ & 15.3 & 9.89 & 5.80 \\
\hline & $\mathrm{G}_{1} \mathrm{~T}_{0}$ & 13.3 & 9.89 & 5.80 \\
\hline & $\mathrm{G}_{1} \mathrm{~T}_{1}$ & 7.3 & 9.89 & 5.80 \\
\hline \multirow{4}{*}{ Desember 2014} & $\mathrm{G}_{0} \mathrm{~T}_{0}$ & 15.3 & 10.29 & 5.88 \\
\hline & $\mathrm{G}_{0} \mathrm{~T}_{1}$ & 6.3 & 10.29 & 5.89 \\
\hline & $\mathrm{G}_{1} \mathrm{~T}_{0}$ & 4.5 & 10.02 & 6.02 \\
\hline & $\mathrm{G}_{1} \mathrm{~T}_{1}$ & 0.3 & 10.06 & 6.04 \\
\hline \multirow{4}{*}{ April 2015} & $\mathrm{G}_{0} \mathrm{~T}_{0}$ & 5.3 & 10.49 & 6.00 \\
\hline & $\mathrm{G}_{0} \mathrm{~T}_{1}$ & 5.3 & 10.42 & 6.26 \\
\hline & $\mathrm{G}_{1} \mathrm{~T}_{0}$ & 5.3 & 10.48 & 6.29 \\
\hline & $\mathrm{G}_{1} \mathrm{~T}_{1}$ & 0.3 & 10.50 & 6.30 \\
\hline
\end{tabular}

Keterangan : $\mathrm{G}_{0}=$ tanpa teras gulud; $\mathrm{G}_{1}=$ dengan teras gulud; $\mathrm{T}_{0}=$ tanpa tanaman penutup tanah; $\mathrm{T}_{1}=$ dengan tanaman penutup tanah ( $N$. biserrata)

*) Hasil pengamatan di lapangan bersama dengan Yenni Asbur dengan kajian yang berbeda 


\section{Kesimpulan}

1. Penanaman $N$. biserrata sebagai tanaman penutup tanah meningkatkan kadar air tanah rata-rata harian baik dan pada lahan tanpa teras gulud maupun dengan teras gulud.

2. Lahan yang diberi teras gulud dan ditanami $N$. biserrata, tanpa teras gulud dan ditanami $N$. biserrata, teras gulud tanpa ditanami $N$. biserrata efektif mengurangi aliran permukaan berturut-turut sebesar $95.7 \%, 80.0 \%$ dan $63.4 \%$

3. Teras gulud dan tanaman penutup tanah $N$. biserrata mempengaruhi tingkat pertumbuhan dan produksi kelapa sawit karena adanya ketersediaan air yang cukup bagi tanaman kelapa sawit terutama pada peubah pertumbuhan yaitu jumlah pelepah dan jumlah pelepah sengkleh.

\section{Ucapan Terima Kasih}

Kepada Pusat Penelitian Kelapa Sawit (PPKS) Medan, Sumatera Utara yang telah mendanai seluruh penelitian ini dan PT. Perkebunan Nusantara VII Lampung yang telah memberikan ijin lokasi penelitian.

\section{Daftar Pustaka}

Adiwiganda, RH., H. Siregar, E.S. Sutarta. 1999. Agroclimatic zones for oil palm (Elaeis guineensis Jacq.) plantation in Indonesia. In Proceedings 1999 PORIM International Palm Oil Congress, "Emerging Technologies and Opportunities in Next Millennium". Palm Oil Research Institute of Malaysia, Kuala Lumpur. pp.387- 401

Ariyanti, M. , S. Yahya , K. Murtilaksono, Suwarto, H.H.Siregar. 2015b. Peranan tanaman penutup tanah Nephrolepis biserrata terhadap neraca air di perkebunan kelapa sawit Lampung Selatan. J. Pen. Kelapa Sawit 23 (2): 61-68.

Arsyad, S. 2010. Konservasi Tanah dan Air. IPB Press. Bogor. 466 hal.
Brata, KR., Sudarmo, P. Djojoprawiro. 1992. Pemanfaatan sisa tanaman sebagai mulsa vertikal dalam konservasi tanah dan air pala pertanian lahan kering di tanah Latosol Darmaga. Jurusan Tanah. Fakultas Pertanian IPB. Bogor.

Chan, HY., N.K. Soong, C.B Wong, A.K. Chiang. 1973. Management of soil under Hevea in West Malaysia. Proc. RRIM Planters' Conf. Kuala Lumpur.

Kartasapoetra. 1989. Kerusakan Tanah Pertanian dan Usaha untuk Merehabilitasinya. Bina Aksara. Jakarta.

Kirkham, MB. 1990. Plant responses to water deficits: In BA Stewart \& DR (Ed). Madison, Wisconsin (US): Irrigation of Agricultural Crops.

Mahamooth, TN., H.H. Gan, K.K. Kee, K.J. Goh. 2008. Water requirements and cycling of oil palm. Sarawak (MY): Proceedings of Agronomy Crop Trust (ACT) Agronomic Principles and Practices of Oil palm Cultivation.

Nasution, U. 1984. Pengamatan berbagai jenis tumbuhan penutup tanah di perkebunan karet. Proc. Lokakarya Penelitian Karet. PN/PT Kebun Wilayah I, Medan, 14-16 Nov. 1984.

Pratiwi, I. 2008. Pengaruh guludan dan rorak terhadap produksi kelapa sawit di unit usaha Rejosari PTPN VII Lampung Selatan [skripsi]. Bogor (ID): Institut Pertanian Bogor.

Purba, RY. 2009. Penyakit-penyakit kelapa sawit (Elaeis guineensis Jacq.) di Indonesia. PPKS. Medan.

Sinukaban, N. 1985. Pengaruh penggunaan mulsa terhadap aliran permukaan, erosi dan selektivitas erosi pada Latosol Darmaga. Jurusan Tanah. Fakultas Pertanian IPB. Bogor.

Suryana, T. 1993. Pengaruh mulsa vertikal terhadap aliran permukaan dan erosi pada Latosol (Oxic Dystropept) Darmaga selama satu musim pertanaman jagung (Zea mays L.) varietas $C P$ 1 [skripsi]. Bogor (ID): Institut Pertanian Bogor.

Tobing, ML. 1994. Pengaruh mulsa vertikal terhadap aliran permukaan, erosi serta pertumbuhan dan produksi selama satu musim tanam kacang tanah varietas Gajah pada tanah Latosol [skripsi]. Bogor (ID): Institut Pertanian Bogor. Trading, Bogor, Indonesia. 